\title{
ANALISIS KESULITAN BELAJAR SISWA PADA MATERI INVERTEBRATA DI KELAS X SMA SE-KECAMATAN PANCUR BATU KABUPATEN DELI SERDANG TAHUN PEMBELAJARAN 2016/2017
}

\author{
Jesaya Surbakti, Martina Asiati Napitupulu \\ Program Studi Pendidikan Biologi, FMIPA, Universitas Negeri Medan \\ J. Willem Iskandar Pasar V Medan Estate Fax. (061) 614002-613319, Medan, Indonesia, 20221 \\ E-mail: jesayasurbakti38@gmail.com
}

\begin{abstract}
ABSTRAK
Penelitian ini bertujuan untuk mengetahui tingkat kesulitan belajar siswa pada materi invertebrata di kelas X SMA dari aspek kognitif, berdasarkan indikator pembelajaran, dan faktor penyebab kesulitan belajar siswa kelas X SMA se-Kecamatan Pancur Batu Tahun pembelajaran 2016/2017. Desain penelitian yang digunakan adalah deskriptif-kuantitatif. Populasi dalam penelitian adalah seluruh siswa Kelas X SMA. Sampel diambil secara cluster random sampling yaitu SMA Negeri 1 Pancur Batu, SMA Swasta Anastasia Pancur Batu dan SMA Rakyat Pancur Batu dengan jumlah siswa 171 orang di SMA se-Kecamatan Pancur Batu. Teknik pengumpulan data yang digunakan adalah tes hasil belajar siswa pada materi invertebrata dan angket dengan siswa yang mengalami kesulitan belajar siswa. Hasil penelitian menunjukkan bahwa persentase kesulitan belajar siswa pada aspek kognitif tingkat pengetahuan (C1) 25,91\% (sedang), tingkat pemahaman (C2) 29,86\% (sedang), tingkat penerapan (C3) 34,91\% (sedang), tingkat analisis (C4) 49,79\% (sangat tinggi), tingkat evaluasi (C5) 60,39\% (sangat tinggi), tingkat kreasi (C6) 49,19\% (sangat tinggi). Pada indikator pembelajaran diperoleh satu kriteria kesulitan belajar pada materi invertebrata yaitu indikator enam berupa menjelaskan siklus hidup anggota hewan invertebrata. Dilihat dari Faktor yang mempengaruhi kesulitan belajar siswa yang paling dominan pada faktor internal yaitu psikiatik sebesar 80,83\% dan kesehatan sebesar 78,61 dengan kategori menghambat kesulitan belajar, sedangkan pada faktor eksternal yaitu sekolah sebesar $78,46 \%$ dan mata pelajaran sebesar $65,47 \%$ dengan kategori menghambat kesulitan belajar.
\end{abstract}

Kata kunci: kesulitan belajar, kognitif, dan invertebrata

\begin{abstract}
This research aims to know the difficulty of student learning on the matter of invertebrates in class X SMA from cognitive, learning-based indicator, and the factors causing difficulty learning the students of class $X$ SMA from the Sub-district Pancur Batu learning Year 2016/2017. The design of the research that is used is the descriptive quantitative. The population in the research is that all the students of class X SMA. Samples taken in a cluster random sampling Pancur Batu namely SMA Negeri 1 Pancur Batu, SMA Anastasia Pancur Batu, and SMA Rakyat Pancur Batu with the number of students 171 people's Senior in High School students from the sub-district Pancur Batu. Data collection technique that is used is the test the results of student learning on the matter of invertebrates and questionnaires with students who have learning difficulties. The results of the study showed that the percentage of students learning difficulties On cognitive knowledge level (C1) $25.91 \%$ percent with the category of difficulty is the level of understanding (C2) $29.86 \%$ with the category of medium difficulty, implementation levels (C3) $34.91 \%$ with the category of difficulty medium, analysis levels (C4) $49.79 \%$ percent with the category of difficulty is very high, evaluation levels (C5) $60.39 \%$ with category of difficulty is very high level of creation (C6) $49.19 \%$ with a very high level of difficulty category. The factors that influence the difficulty of learning the most dominant is the internal factors namely pscyhiatric of $80.83 \%$ and the health of $78.61 \%$ with the cause of the difficulties learning, while external factors namely schools of $78.46 \%$ and subjects of $65.47 \%$ with the cause of the difficulties learning.
\end{abstract}

Keywords: difficulties learning, cognitive, and invertebrates

\section{PENDAHULUAN}

Proses pendidikan berlangsung dalam suatu proses yang disebut dengan belajar. Menurut Syah (2010), belajar merupakan kegiatan yang berproses dan menjadi unsur fundamental bagi berlangsungnya proses pendidikan. Hal ini akan terjadinya tujuan pendidikan bergantung pada proses belajar yang dialami oleh setiap peserta didik.
Proses belajar bukan hanya berlangsung di sekolah tetapi juga di lingkungan rumah dan sekitarnya.

Tugas seorang siswa adalah belajar, oleh karena itu seorang siswa perlu memiliki kebiasaan belajar yang baik sehingga dapat mencapai prestasi yang optimal. Hasil penelitian yang dilakukan Amti dan Marjohan (1993) menunjukkan bahwa adanya 
hubungan yang berarti antara kebiasaan belajar dengan hasil belajar. Hal ini berarti siswa yang mempunyai kebiasaan belajar yang baik akan memperoleh nilai yang baik. Pembelajaran di sekolah adalah salah satu tahap yang sangat menentukan ketuntasan belajar siswa. Guru sebagai salah satu mediator dan nilai merupakan indikator dari ketuntasan belajar (Ristiyani, 2016).

Proses pembelajaran yang maksimal di sekolah tidak mudah untuk diaplikasikan karena guru sering berhadapan dengan masalah-masalah termasuk dalam menentukan teknik, metode dan media yang sesuai dengan karakter siswa. Bila kegiatan belajar tidak berhasil dan siswa tidak mampu mengaitkan antara pengetahuan baru dengan pengetahuan lamanya sehingga menimbulkan ketidakpahaman atau ketidakjelasan terhadap suatu pelajaran maka siswa mengalami kesulitan belajar (Slameto, 2003).

Pada umumnya, kesulitan belajar siswa merupakan suatu kondisi belajar yang ditandai dengan adanya hambatan dalam kegiatan pembelajaran sehingga memerlukan usaha lebih giat untuk dapat mengatasinya. Kesulitan belajar siswa dapat dilihat dari hasil belajar yang dicapai oleh siswa. Aktivitas belajar siswa tidak selamanya berjalan dengan lancar. Hal ini dapat dilihat dari cara menangkap pelajaran yang kadang-kadang cepat atau lama dan sebaliknya. Mata pelajaran biologi termasuk salah satu mata pelajaran yang kompleks, karena didalamnya tercakup seluruh makhluk hidup. Proses pembelajaran biologi mengandung proses keterampilan yaitu mengamati, menggolongkan, mengukur, menggunakan alat, serta hasil melalui beberapa cara seperti lisan, tulisan dan diagram, dan melakukan percobaan. Hal ini menyebabkan para siswa mengalami hambatan atau kesulitan dalam belajar biologi, seperti tidak tersedianya sarana dan prasarana yang memadai dalam mendukung proses belajar biologi (Sianturi, 2016).

Berdasarkan hal tersebut, maka perlu dilakukan penelitian untuk mengetahui tingkat kesulitan yang dialami siswa kelas X SMA seKecamatan Pancur Batu dalam mempelajari materi invertebrata Tahun Pembelajaran 2016/2017, mengetahui kesulitan pada indikator pembelajaran invertebrata serta faktor-faktor yang mempengaruhi kesulitan belajar siswa pada materi invertebrata.

\section{METODE PENELITIAN}

Penelitian deskriptif ini dengan populasi penelitian adalah seluruh siswa kelas X SMA di Kecamatan Pancur Batu yang terdiri dari 7 sekolah. Teknik pengambilan sampel dalam dalam penelitian ini adalah dengan menggunakan teknik cluster random sampling yang diacak dari ketujuh sekolah di Kecamatan Pancur Batu yaitu SMA Negeri 1 Pancur Batu dengan jumlah 105 siswa, SMA Swasta Anastasia Pancur Batu dengan jumlah 26 siswa, dan SMA Rakyat Pancur Batu dengan jumlah 40 siswa, dengan total jumlah siswa sebayak 171 orang.

Pengumpulan data pada penelian ini dilakukan dengan cara memberikan tes hasil belajar materi invertebrata sebanyak 30 soal, dan angket kesulitan belajar materi invertebrata sebanyak 40 soal. Hal ini digunakan untuk memperoleh data hasil belajar materi invertebrata dalam bentuk tes pilihan berganda (multiple choice). Siswa yang memperoleh nilai dibawah KKM 75 akan diberikan angket kesulitan belajar yang terdiri dari 40 item angket.

Analisis data yang digunakan dalam penelitian ini adalah teknik analisis deskriptif untuk menggambarkan data yang diambil dalam penelitian ini adalah hasil dari jawaban siswa terhadap instrumen tes materi invertebrata, kemudian dianalisis dengan cara menghitung nilai dan persentase daya serap kesulitan belajar dan menetapkan kriteria tingkat kesulitan belajar.

\section{HASIL PENELITIAN}

\section{Hasil Belajar Siswa Pada Materi Invertebrata}

Hasil belajar siswa pada materi invertebrata dari tiga sekolah yaitu SMA Negeri 1 Pancur Batu, SMA Anastasia Pancur Batu, dan SMA Rakyat Pancur Batu terdiri 171 siswa yang ikut dalam tes diagnostik diperoleh nilai rata-rata hasil belajar sebesar $67,09 \%$, yang meliputi nilai rata-rata SMA Negeri 1 Pancur Batu sebesar 68,00\%, SMA Anastasia Pancur Batu sebesar 71,72\%, dan SMA Rakyat Pancur Batu sebesar 61,56\%. Hasil tes kesulitan belajar siswa pada materi invertebrata dapat dilihat pada Tabel 1.

Tabel 1. Jumlah Nilai Rata-Rata Siswa Kelas X SMA se-Kecamatan Pancur Batu Tahun Pembelajaran 2016/2017

\begin{tabular}{lc}
\hline \multicolumn{1}{c}{ Nama Sekolah } & Nilai Rata-Rata (\%) \\
\hline SMA Negeri 1 Pancur Batu & 68,00 \\
SMA Swasta Anastasia Pancur Batu & 71,72 \\
SMA Swasta Rakyat Pancur Batu & 61,56 \\
Nilai Rata-Rata & 67,09 \\
\hline
\end{tabular}


Dari 171 orang siswa atau sebanyak 120 orang siswa $(70,18 \%)$ tidak tuntas pada materi invertebrata, yaitu sebanyak 60 orang siswa dari SMA Negeri 1 Pancur Batu, 20 orang siswa dari SMA

Aspek kognitif merupakan salah suatu aspek yang berhubungan dengan proses berpikir siswa guna mengetahui atau memahami materi invertebrata. Wujud dari penggunaan fungsi kemampuan kognitif dapat dilihat dari kemampuan siswa dalam mengerjakan soal-soal materi invertebrata. Menurut Bloom, terdapat enam jenjang proses berfikir, mulai dari jenjang terendah sampai jenjang yang tertinggi yang meliputi enam
Anastasia Pancur Batu, dan 40 orang siswa dari SMA Rakyat Pancur Batu.

\section{Kesulitan Belajar Materi Invertebrata Berdasarkan Aspek Kognitif}

tingkatan (C1: pengetahuan, C2: pemahaman, C3: Penerapan, C4: Analisis, C5: Sintesis, C6: Kreasi).

Rata-rata kesulitan belajar siswa pada aspek kognitif dapat disajikan dalam bentuk diagram gambar yang dapat dilihat pada Gambar 1 . Berdasarkan Gambar 1. dapat dilihat bahwa soal pada aspek kognitif C5 yang termasuk dalam kriteria kesulitan belajar yang tertinggi yaitu C5 (sintesis) sebesar 60,39\%, C4 (analisis) sebesar 49,79\%, dan C6 (kreasi) sebesar 49,19\%.

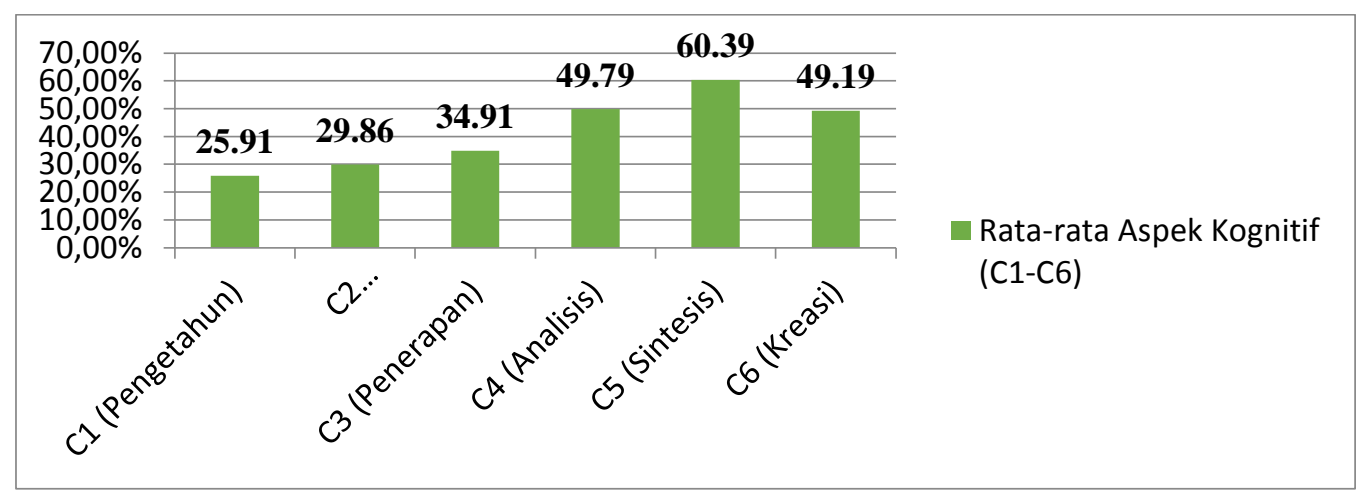

Gambar 1. Persentase (\%) Rata-rata Kesulitan Belajar Pada Aspek Kognitif Materi Invertebrata Kelas X SMA se-Kecamatan Pancur Batu

\section{Kesulitan Belajar Materi Invertebrata Berdasarkan Aspek Indikator Pembelajaran}

Aspek indikator pembelajaran invertebrata menjadi pedoman dalam merancang, melaksanakan, serta mengevaluasi hasil belajar siswa. Rancangan serta evaluasi tersebut akan memberikan acuan dalam menentukan hasil belajar materi invertebrata pada siswa. Aspek indikator pembelajaran materi invertebrata, ditemukan dari silabus pembelajaran materi pokok invertebrata. Pada silabus pembelajaran tersebut mencakup delapan indikator pembelajaran invertebrate. Rata-rata kesulitan belajar siswa pada aspek indikator dapat disajikan dalam bentuk diagram gambar yang dapat dilihat pada Gambar 2. Berdasarkan diagram dapat dilihat bahwa indikator pembelajaran yang mengalami kriteria kesulitan belajar adalah indikator 6 yaitu menjelaskan siklus hidup anggota hewan invertebrata sebesar $52,50 \%$.

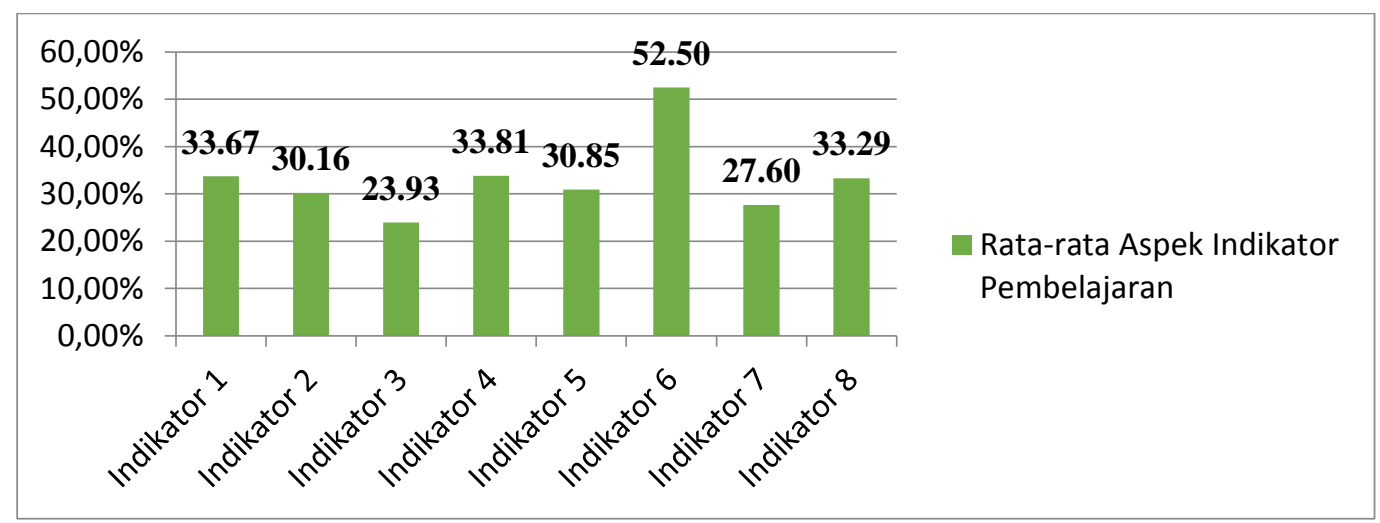

Gambar 1. Persentase (\%) Rata-rata Kesulitan Belajar Pada Aspek Indikator Pembelajaran Materi Invertebrata Kelas X SMA se-Kecamatan Pancur Batu 
Halaman : $066-071$

\section{Keterangan:}

Indikator 1 = Mengidentifikasi ciri-ciri umum invertebrata

Indikator 2 = Menjelaskan dasar klasifikasi dunia hewan invertebrata

Indikator 3 = Membandingkan ciri-ciri masing-masing filum hewan invertebrata

Indikator 4 = Menjelaskan beberapa contoh spesies hewan invertebrata

Indikator 5 = Menggambarkan struktur tubuh hewan invertebrata

Indikator 6 = Menjelaskan siklus hidup anggota hewan invertebrata

Indikator 7 = Menjelaskan sistem metabolisme pada hewan invertebrata

Indikator 8 = Menjelaskan peranan hewan invertebrata bagi kehidupan manusia

\section{Angket Kesulitan Belajar Siswa}

Angket sebagai alat pengumpul data yang berisikan pertanyaan-pertanyaan tertulis dan yang akan dijawab secara tertulis pula oleh siswa. Angket yang diberikan kepada siswa digunakan untuk memperoleh informasi dari siswa tentang kesulitan belajar siswa pada materi invertebrata. Pada angket yang digunakan pada penelitian ini, terdapat sembilan indikator-indikator yang menunjukkan kesulitan belajar siswa dan dikelompokkan menjadi dua faktor yaitu faktor internal dan eksternal yang dapat dilihat pada Tabel 3 dan Tabel 4. Berdasarkan Tabel 3 terdapat dua indikator pada faktor eksternal yang memiliki kriteria yang menghambat belajar pada materi invertebrata yaitu indikator sekolah sebesar $78,46 \%$, dan indikator materi invertebrata sebesar $65,47 \%$.

Tabel 3. Kategori Faktor Eksternal Penyebab Kesulitan Belajar Siswa Di Kelas X SMA se-Kecamatan Pancur Batu

\begin{tabular}{lccccc}
\hline $\begin{array}{l}\text { Faktor Eksternal } \\
\text { Kesulitan Belajar }\end{array}$ & $\begin{array}{c}\text { SMA Negeri 1 } \\
\text { Pancur Batu } \\
(\%)\end{array}$ & $\begin{array}{c}\text { SMA Anastasia } \\
\text { Pancur Batu } \\
(\%)\end{array}$ & $\begin{array}{c}\text { SMA Rakyat } \\
\text { Pancur Batu } \\
(\%)\end{array}$ & $\begin{array}{c}\text { SMA se- } \\
\text { Kecamatan } \\
\text { Pancur Batu (\%) }\end{array}$ & Kategori Kesulitan \\
\hline $\begin{array}{l}\text { 1. Lingkungan } \\
\quad \text { Keluarga }\end{array}$ & 60,10 & 56,56 & 55,16 & 57,86 & Cukup Menghambat \\
$\begin{array}{l}\text { 2. Sekolah } \\
\text { 3. Materi }\end{array}$ & 77,17 & 78,00 & 80,62 & 78,46 & Menghambat \\
$\quad$ Invertebrata & 89,31 & 66,56 & 64,53 & 65,47 & Menghambat \\
4. Media & 51,35 & 42,34 & 48,98 & 49,79 & Cukup Menghambat \\
\hline
\end{tabular}

Tabel 4. Kategori Faktor Internal Penyebab Kesulitan Belajar Siswa Di Kelas X SMA se-Kecamatan Pancur Batu

\begin{tabular}{lccccc}
\hline $\begin{array}{c}\text { Faktor Internal } \\
\text { Kesulitan Belajar }\end{array}$ & $\begin{array}{c}\text { SMA Negeri } \\
\text { 1 Pancur } \\
\text { Batu (\%) }\end{array}$ & $\begin{array}{c}\text { SMA Swasta } \\
\text { Anastasia } \\
\text { Pancur Batu (\%) }\end{array}$ & $\begin{array}{c}\text { SMA Swasta } \\
\text { Rakyat Pancur } \\
\text { Batu (\%) }\end{array}$ & $\begin{array}{c}\text { SMA se- } \\
\text { Kecamatan } \\
\text { Pancur Batu (\%) }\end{array}$ & Kategori Kesulitan \\
\hline 1. Kesehatan & 77,22 & 73,33 & 83,33 & 78,61 & Menghambat \\
2. Intelegensi & 63,54 & 50,62 & 53,16 & 61,25 & Menghambat \\
3. Minat & 62,92 & 59,58 & 65,62 & 63,26 & Menghambat \\
4. Motivasi & 88,33 & 58,12 & 64,84 & 64,43 & Menghambat \\
5. Psikiatik & 81,25 & 80,62 & 80,31 & 80,83 & Menghambat \\
\hline
\end{tabular}

Berdasarkan Tabel 4 terdapat lima indikator pada faktor internal yang memiliki kriteria yang menghambat belajar materi pada materi invertebrata yaitu indikator psikiatik sebesar

\section{PEMBAHASAN}

Hasil penelitian diatas menunjukkan bahwa siswa mengalami peningkatan level kesulitan belajar seiring dengan jenjang atau tingkatan taksonomi Bloom yang lebih tinggi (high order thinking). Pada level ini, tingkat kesulitan yang dihadapi siswa masuk dalam kategori kesulitan belajar invertebrata yang sangat tinggi. Siswa dapat dikategorikan tidak
$80,83 \%$, indikator kesehatan sebesar $78,61 \%$, indikator motivasi sebesar $64,43 \%$, indikator minar sebesar 63,26\%, dan indikator intelegensi sebesar $61,25 \%$.

memiliki kemampuan analisis, evaluasi, dan kreasi. Hal ini sejalan dengan pendapat yang mengatakan bahwa semakin tinggi tingkat soal, maka semakin tinggi pula tingkat kesulitan belajar invertebrata yang dialami siswa dalam menjawab soal-soal materi invertebrata. 
Hasil penelitian ini juga mengatakan, tidak ada soal invertebrata dari aspek kognitif yang dianggap mudah oleh siswa dari ketiga sekolah (SMA Negeri 1 Pancur Batu, SMA Swasta Anastasia Pancur Batu, dan SMA Rakyat Pancur Batu). Hal ini disebabkan oleh beberapa hal yaitu adanya soal materi invertebrata yang masih belum standar pada buku pegangan siswa. Lokasi sekolah tidak terletak dikota besar, hal ini akan berpengaruh terhadap belajar biologi khususnya materi invertebrata.

Bimbingan belajar atau les sore merupakan salah satu pendukung dalam belajar invertebrata siswa. Siswa kelas X SMA di ketiga sekolah yaitu SMA Negeri 1 Pancur Batu, SMA Swasta Anastasia Pancur Batu, dan SMA Rakyat Pancur Batu tidak mengikuti bimbingan belajar atau les sore. Hal ini mengakibatkan siswa tidak terbiasa untuk menjawab soal-soal ujian tes materi invertebrata. Selain itu, kesulitan belajar invertebrata tidak terlepas dari kurangnya faktor pendukung sarana/prasarana belajar siswa seperti buku biologi siswa, alat dan bahan praktikum serta alat-alat elektronik yang memudahkan siswa untuk mendapatkan informasi terbaru mengenai materi invertebrata. Di SMA Swasta Anastasia Pancur Batu dan SMA Swasta Rakyat Pancur Batu memiliki ruangan laboratorium dengan alat dan bahan yang minim. Sedangkan pada SMA Negeri 1 Pancur Batu memiliki laboratorium dengan alat dan bahan yang baik. Hal ini membantu siswa Kelas X SMA Negeri 1 Pancur Batu dalam belajar biologi.

Indikator keenam yaitu menjelaskan siklus hidup invertebrata termasuk dalam ketrampilan berfikir (high order thinking). Pada indikator ini siswa harus memiliki empat tingkat ketrampilan berfikir (high order thinking) yaitu menghafal (recall thinking), kritis (critical thinking), dasar (basic thinking), dan kreatif (creative thinking). Siswa dapat dikategorikan tidak memiliki ketrampilan menghafal (recall thinking), kritis (critical thinking), dasar (basic thinking), dan kreatif (creative thinking) secara keseluruhan.

Hasil penelitian ini juga mengatakan, hanya ada satu sekolah yang tidak mengalami kesulitan pada indikator keenam yaitu SMA Negeri 1 Pancur Batu yang dikarenakan fasilitas sekolah yang mendukung pembelajaran seperti tersedianya infokus sebanyak 3 buah, laboratorium yang memiliki alat dan bahan praktikum yang memadai seperti tersedianya mikroskop 1 buah, alkohol, spiritus, objek glass, dan lainnya serta ruangan belajar yang bersih dan terdapat kipas angin serta dinding keramik yang membuat siswa nyaman untuk belajar. Sedangkan pada SMA Swasta Anastasia Pancur Batu dan SMA Swasta Rakyat Pancur Batu mengalami kesulitan belajar pada indikator enam karena fasilitas sekolah yang tidak lengkap seperti laboratorium yang didalamnya tidak ada mikroskop hanya terdapat alkohol, spiritus, serta objek glass (hanya terdapat bahan dasar praktikum saja), serta ruangan kelas pada SMA Swasta Anastasia dan SMA Rakyat Pancur Batu tidak memiliki kipas angina serta ruangan yang tidak berkeramik yang membuat siswa kurang nyaman dalam belajar materi invertebrata dikelas.

Indikator sekolah dan materi invertebrata merupakan indikator yang menunjukkan angka tertinggi $(78,46 \%$ dan $65,47 \%)$ pada faktor eksternal. Hal ini mengindikasikan bahwa kedua indikator ini merupakan indikator penghambat belajar invertebrata pada siswa. Pada indikator sekolah, SMA Negeri 1 Pancur Batu lebih baik dengan data sebesar 77,17\%, dibandingkan SMA Swasta Anastasia Pancur Batu sebesar $78,00 \%$, dan SMA Swasta Rakyat Pancur sebesar $78,46 \%$. Hal ini terlihat pada fasilitas sarana dan prasarana memadai pada SMA Negeri 1 Pancur Batu yang terlihat dari alat dan bahan laboratorium yang baik seperti adanya sebuah mikroskop dan bahan-bahan praktikum yang memadai untuk melaksanakan praktikum, adanya infokus sebanyak tiga buah sebagai media pembelajaran, serta suasana ruangan kelas yang memiliki kipas angin dan dinding yang berkeramik sehingga membuat ruangan kelas bersih, rapi, dan nyaman. Sedangkan pada SMA Swasta Anastasia Pancur Batu dan SMA Swasta Rakyat Pancur Batu masih minim akan fasilitas sarana dan prasarana sekolah yang dapat menghambat belajar invertebrata seperti papan tulis yang kurang bersih di SMA Swasta Anastasia Pancur Batu, dan SMA Rakyat Pancur Batu, ruangan kelas yang belum terpasang kipas angin dan dinding keramik yang membuat siswa kurang nyaman saat belajar materi invertebrata.

Hal ini disebabkan oleh siswa SMA Negeri 1 Pancur Batu, SMA Swasta Anastasia Pancur Batu, dan SMA Swasta Rakyat Pancur Batu tidak memanfaatkan waktunya untuk belajar serta ketidaktahuan siswa terhadap standard tugas yang diberikan oleh guru sehingga siswa tidak memberikan $100 \%$ niatnya untuk konsentrasi saat belajar materi invertebrata. Hal ini sejalan dengan Penelitian yang dilakukan C.C. Wrenn dan Reginald Bell (Bennett, 1952) menyatakan faktor yang menyebabkan kesulitan belajar adalah kesulitan mengatur waktu belajar (difficulty in budgeting time), ketidaktahuan mengenai standar tugas yang harus dipenuhi, dan kebiasaan membaca yang lambat sehingga mempengaruhi psikis siswa untuk belajar. 
Indikator kesehatan merupakan indikator tertinggi kedua setelah psikiatik. Data penelitian ini, menunjukkan: SMA Swasta Anastasia Pancur Batu sebesar 73,33\% lebih baik dibandingkan SMA Negeri 1 Pancur Batu sebesar 77,22\%, dan SMA Swasta Rakyat Pancur Batu sebesar 83,33\%. Hal ini dikarenakan lokasi SMA Swasta Anastasia Pancur Batu jauh dari pusat kebisingan/keramaian, sedangkan SMA Negeri 1 Pancur Batu lokasi sekolah terletak di pinggir jalan Djamin Ginting yang merupakan jalan provinsi dan terletak di dekat pasar Pancur Batu sehingga dapat menganggu pendengaran siswa dalam belajar invertebrata, SMA Swasta Rakyat Pancur Batu lokasi sekolah terletak di pinggir jalan Djamin Ginting yang merupakan jalan provinsi sehingga dapat menganggu pendengaran siswa saat guru mengajarkan materi invertebrata.

\section{SIMPULAN}

Berdasarkan uraian dai hasil penelitian dan pembahasan, maka diperoleh simpulan antara lain: (1) Tingkat kesulitan belajar siswa pada materi invertebrata di kelas X SMA se-Kecamatan Pancur Batu Tahun Pembelajaran 2016/2017 dari aspek kognitif yang paling dominan yaitu pada soal sintesis (C5) sebesar 60,39\%, soal analisis (C4) sebesar $49,79 \%$, soal kreasi (C6) sebesar $49,19 \%$. (2) Tingkat kesulitan belajar siswa pada materi invertebrata di kelas X SMA se-Kecamatan Pancur Batu Tahun Pembelajaran 2016/2017 dari indikator pembelajaran invertebrata yang paling dominan yaitu pada indikator 6: menjelaskan siklus hidup anggota hewan invertebrata sebesar $52,50 \%$. (3) Faktor-faktor penyebab yang menghambat kesulitan belajar pada materi invertebrata di kelas X SMA seKecamatan Pancur Batu yang paling dominan yaitu pada faktor internal berupa psikiatik sebesar $80,83 \%$ dan kesehatan sebesar 78,61\%, serta faktor eksternal berupa sekolah sebesar 78,46\%.

\section{DAFTAR PUSTAKA}

Amti, Erman \& Marjohan, (1993), Bimbingan dan Konseling. Jakarta: Depdikbud.

Arikunto, S., (2013), Prosedur Penelitian, Penerbit Rineka Cipta, Jakarta.

Pujayanto, dkk, (2013), Analisis Pencapaian Kompetensi Kognitif Tingkatan Aplikasi (C3) Dan Analisis (C4) Dalam Pembelajaran Fisika Pada Siswa Berkesulitan Belajar. Jurnal Pendidikan Fisika. 1:1-.

Sianturi, (2016), Analisis Kesulitan Belajar Dan Hubungannya Dengan Hasil Belajar Siswa Pada Mata Pelajaran Biologi Siswa Kelas $X$ Di SMA Negeri 1 Sidikalang Tahun
Pembelajaran 2015/2016, Jurnal Pelita Pendidikan. 1:170-178.

Slameto, (2003), Belajar dan Faktor-faktor yang Mempengaruhinya, Penerbit Rineka Cipta, Jakarta.

Soemanto, W., (2006), Psikologi Pendidikan, Rineka Cipta, Jakarta.

Sudjana, N., (2010), Penilaian Hasil Proses Belajar Mengajar, Tarsito, Bandung.

Sudijono, A., (2009), Evaluasi Pendidikan, Rajawali Pers, Jakarta.

Syah, M., (2000), Psikologi Pendidikan dengan Pendekatan Baru, Penerbit Remaja Rosdakarya, Bandung. 